\title{
Radical-Scavenging Activity of Fish Gelatin Hydrolysates from Bone of Pangasius catfish (Pangasius sutchi) by Microbial Proteases Hydrolysis
}

\author{
Yoni Atma $^{1 * \mathbb{D}}$, Dita Fitriani 1 ${ }^{1 D}$, Apon Zaenal Mustopa ${ }^{2}$ iD \\ 1 Department of Food Science and Technology, Faculty of Bioindustry, Universitas Trilogi, Jakarta, Indonesia \\ 2 Research Center for Biotechnology, Indonesian Institute of Science, Bogor, Indonesia \\ * Correspondence: yoniatma@trilogi.ac.id;
}

Scopus Author ID 57194092488

Received: 5.06.2020; Revised: 29.06.2020; Accepted: 1.07.2020; Published: 5.07.2020

\begin{abstract}
The gelatin extracted from the bone of Indonesian Pangasius sutchi was hydrolyzed using two proteases, namely protease Lactobacillus plantarum S31, which isolating from bekasam (an Indonesian fermented fish product) and flavourzyme (a commercial enzyme from Aspergillus oryzase). The concentrations of enzymes for hydrolysis were $1 \%$ and $6 \%$ based on enzyme/substrate [E/S] ratio. The bioactivity of the hydrolysates as an antioxidant was measured based on their capacity to inhibit 1,1-diphenyl-2-picylhydrazyl (DPPH). The ascorbic acid or vitamin C in the range 50-150 ppm was used as positive controls. The result showed that the bioactivities of all hydrolysates were increased compared to gelatin before hydrolysis. The hydrolysates have a percent of inhibition range that higher than the ascorbic acid. The hydrolysates of gelatin derived from the bone of Pangasius sutchi would be a potential source as raw material for bioactive peptides production with antioxidant activity.
\end{abstract}

Keywords: antioxidant; bioactive peptide; fish gelatin; gelatin hydrolysate; protease.

(C) 2020 by the authors. This article is an open-access article distributed under the terms and conditions of the Creative Commons Attribution (CC BY) license (https://creativecommons.org/licenses/by/4.0/).

\section{Introduction}

Fish based gelatin has been developed in producing bioactive peptides regarding their bioactivities as antioxidants [1], antihypertensive [2], antimicrobial [3], anti-diabetic (type 2) [4] and anticancer [5]. As antioxidants, fish gelatin is taking great attention concerning safety aspects [6], abundance amount, and promising for industrial application [7], as well as their simply hydrolyzed enzymatically in order to obtain higher activity [8, 9]. In addition, some of the antioxidant activity of bioactive peptides influenced by the presence of Glycine (Gly) and Proline (Pro) in which both these amino acids dominantly contain in fish gelatin [10]. A work conducted by Zheng et al. (2018) also concluded that the antioxidant activity of fish gelatin higher than porcine and bovine gelatin [11]. Studies investigating of antioxidant properties attaching to hydrolysates and bioactive peptides from fish gelatin was covering from skins and scales of Nile tilapia [8, 12, 13, 14], Sole fish [15], the skin of Amur sturgeon [16], Cobia [17], Unicorn leatherjacket, Thornback ray [18], Black-barred halfbeak [19], Carp [20], Tuna, Halibut [21], and bone of Skipjack Tuna [22].

Actually, as a source of fish gelatin, the bone of pangasius catfish has higher in yield compared to other fish-based origins [23]. So, this research provides a work using the most promising alternative source of gelatin in terms of considering the quantity of gelatin yield. 
Moreover, this research was conducted to attempt using an enzyme from lactic acid bacteria which convenient for humans, i.e., protease from Lactobacillus plantarum S31. L. plantarum S31 is a bacterium that originated from bekasam (an Indonesian fermented fish product). A study by Budiarto et al. (2016) found that protease from L. plantarum S31 is thermostable [24]. There are several benefits by using thermostable enzymes, including preventing the contaminations, increasing catalysis rates, and reducing viscosity in order to simplify hydrolysates production [25]. The protease from L. plantarum S31 is also proven hydrolyzed protein to become hydrolysates with antioxidant activity [26]. Furthermore, this research was also using commercial protease such as flavourzyme to obtain comparative results. Flavourzyme is a protease expressed by Aspergillus oryzae with endopeptidase and exopeptidase hydrolysis sites. Through more sites that can be hydrolyzed, may implicate to the great possibility of hydrolysates against oxidant agents.

The capacity of fish gelatin hydrolysates against oxidants agents measured by some methods. For instance, radical scavenging, metal chelating or reducing, and lipid peroxidation inhibition activities. It is commonly believed that the radical scavenging activity is the most and represents the parameter measuring the antioxidant activity. The majority of previous researches were using DPPH (1,1 diphenyl 2 picylhydrazyl) radical to determine the radical scavenging activity of fish-based gelatin $[18,19,22,27]$. Cai et al. (2015) support that opinion by stating the DPPH is generally used as a substrate to measuring the antioxidant activity [28]. The method is fast, convenient, and efficient in predicting the antioxidant activity, so it has been broadly adopted to test the ability of compounds to act as free radical scavengers. Yang et al. (2019) mentioned that DPPH is a stable and cell-permeable radical that is commonly applied for analysis antioxidant activity [29]. Thus, for the reasons of deal with efficiency, in this research, we have analyzed the DPPH inhibition activity of pangasius gelatin hydrolysates and terminated the study on hydrolysate activity without purified further because number prior publications were showing the activity of gelatin hydrolysates are better than smaller purified gelatin peptides $[11,28,30]$.

\section{Materials and Methods}

\subsection{Enzyme preparation.}

Lactobacillus plantarum S31 from Research Center for Biotechnology, Indonesian Institute of Science, was used as a source of the first enzyme. The production of extracellular protease from this lactic acid bacteria (LAB) and determination of the protease activity was done by using a method described by Budiarto et al. [24]. Whilst, the second enzyme is flavourzyme (from Aspergillus oryzae), which manufactured by Novozyme Corp. (Bagsvaerd, Denmark).

\subsection{Fish bone gelatin hydrolysates preparation.}

The gelatin from the bone of Pangasius catfish (Pangasius sutchi) extracted in our previous work [31] was used for hydrolysates preparation. The gelatin from the refrigerator placed at room temperature, then mixed using vortex until it became a liquid. Then, the gelatin solution added with each protease in different concentration (E/S ratio) i.e., $1 \%$ and $6 \%(\mathrm{v} / \mathrm{v})$. After that, the gelatin-enzyme solution was incubated for 3 hours. The gelatin with protease from L. plantarum S31 incubated at $\mathrm{pH} 5,37^{\circ} \mathrm{C}$, while the gelatin mixed with flavourzyme 
from $A$. oryzae incubated at $\mathrm{pH} 7,50^{\circ} \mathrm{C}$. The enzymatic hydrolysis was stopped by heating the mixture solutions at $100{ }^{\circ} \mathrm{C}$ for 10 minutes. The hydrolysates were obtained by separation technique using centrifugation at $10,000 \mathrm{rpm}, 15 \mathrm{~min}$, and $4{ }^{\circ} \mathrm{C}$. Finally, the supernatant was collected as fish gelatin hydrolysates and stored at $-20{ }^{\circ} \mathrm{C}$ before further analysis. The protein concentration of gelatin and their hydrolysates quantified using bicinchoninic acid (BCA) assay kit (Thermo Fisher, Rockford, IL, USA) by the method described in our previous work [31].

\subsection{Determination of molecular weight.}

Molecular weight (MW) identification was performed through vertical electrophoresis by using sodium dodecyl sulfate polyacrylamide gel electrophoresis (SDS-PAGE) as explained in our previous study carried out by discontinues Tris/HCl/glycine buffer system [23, 31]. Then, the appearance of bands protein was quantified for their retardation factor (Rf) value by using the formula of $\mathrm{Rf}=$ [the distance of bands of protein movement from starting point] / [the distance of marker movement from starting point]. The molecular weight of each hydrolysate quantified using linear equation $(y=a x+b)$ made from a log of MW ( $y$-axis) and Rf (x-axis).

\subsection{Antioxidant activity.}

Antioxidant activity was determined by measuring the radical scavenging activity of fish gelatin hydrolysates against DPPH (1,1 diphenyl-2- picylhydrazyl). The capacity of gelatin hydrolysates to inhibit free radicals of DPPH was conducted according to Clarke et al. (2013) procedure with some modification through ethanol 96\% addition [32]. Firstly, $20 \mu \mathrm{L}$ samples added with $180 \mu \mathrm{L}$ DPPH solution (a distilled water used as control). After mixing vigorously for $10 \mathrm{~s}$, then the absorbance measured using enzyme-linked immunosorbent assay (ELISA) Microplate Reader (Multiskan Ex, Champaign, IL, USA). The reaction/mixed solution was read at $540 \mathrm{~nm}$ against a reagent blank. The radical scavenging activity was calculated by the following formula: antioxidant activity $(\%)=[(\mathrm{As}-\mathrm{An}) /(\mathrm{Ab}-\mathrm{An})] \times 100$ where As, An, and $\mathrm{Ab}$ were the absorbance values determined at $540 \mathrm{~nm}$ of the samples, the negative control, and the blank after a reaction, respectively $[16,32]$. The $\mathrm{IC}_{50}$ was defined as a concentration of fish gelatin hydrolysates to inhibit free radical as many as fifty percent. The scavenging activity of ascorbic acid (vitamin C) as control positive with different concentrations (50-150 ppm) was also measured as the same as the procedure for quantifying the antioxidant activity of samples.

\subsection{Statistical analysis.}

All value determinations were performed in average values. Numbers were expressed as the means followed by their standard deviations. Analysis of variance was conducted, and differences between variables were analyzed for their significance by Tukey's range test $(\mathrm{p}<$ $0.05)$.

\section{Results and Discussion}

\subsection{Fishbone gelatin hydrolysis.}

Gelatin after hydrolysis was determined their molecular weight (figure 1 and table 1) and protein content (Table 2). It confirmed that gelatin hydrolysates have lower MW compared to crude extract gelatin. The MW of fishbone gelatin hydrolysates is various depend on enzyme 
concentration for hydrolysis. In this study, the MW of gelatin hydrolysates were in the range of $41-63 \mathrm{kDa}$ (figure 1). Fish gelatin that hydrolyzed with extracellular protease from $L$. plantarum S31 has MW slightly higher (51 and $63 \mathrm{kDa})$ than which hydrolyzed with flavourzyme (41 and $43 \mathrm{kDa}$ ).

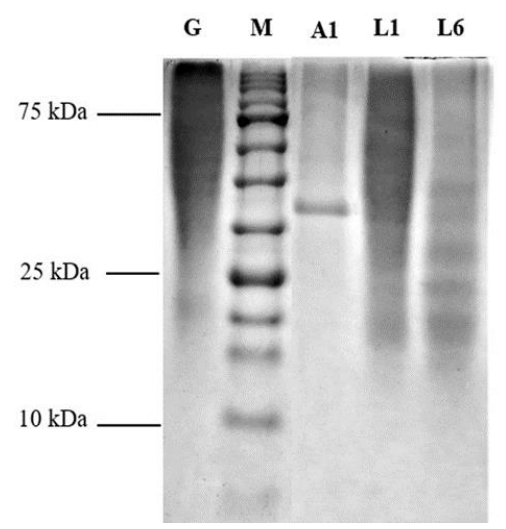

Figure 1. Electroforegram fish gelatin $(\mathrm{G})$ and their hydrolysates. A1=hydrolysate derived from $6 \%[\mathrm{E} / \mathrm{S}]$ protease from A. oryzae, $\mathrm{L} 1=1 \%[\mathrm{E} / \mathrm{S}]$ protease from L. plantarum $\mathrm{S} 31$ and $\mathrm{L} 6=6 \%[\mathrm{E} / \mathrm{S}\}$ protease from L. plantarum $\mathrm{S} 31, \mathrm{M}=$ marker protein.

Table 1. Molecular weight (MW) of fish gelatin and their hydrolysates.

\begin{tabular}{lll}
\hline Samples & Rf samples & MW (kDa) \\
\hline Fish gelatin (before hydrolysis) & 0.059 & $\mathbf{1 6 3}$ \\
& 0.072 & 137 \\
Hydrolysate (1\% E/S ratio L. plantarum S31) & 0.147 & $\mathbf{6 3}$ \\
& 0.188 & 44 \\
& 0.407 & 26 \\
Hydrolysate (6\% E/S ratio L. plantarum S31) & 0.166 & $\mathbf{5 1}$ \\
& 0.194 & 43 \\
& 0.269 & 30 \\
Hydrolysate (1\% E/S ratio A. oryzae) & 0.327 & 27 \\
& 0.544 & 21 \\
& 0.189 & $\mathbf{4 3}$ \\
Hydrolysate (6\% E/S ratio A. oryzae) & 0.309 & 28 \\
& 0.458 & 25 \\
& 0.204 & $\mathbf{4 1}$ \\
& 0.316 & 28 \\
\hline
\end{tabular}

Table 2. Protein content of fish gelatin and their hydrolysates.

\begin{tabular}{ll}
\hline Samples & Protein content \\
\hline Fish gelatin & $1.83_{\mathrm{cd}} \pm 0.100$ \\
Hydrolysate $(1 \%$ E/S ratio L. plantarum S31) & $0.80_{\mathrm{d}} \pm 0.155$ \\
Hydrolysate $(6 \%$ E/S ratio L. plantarum S31) & $1.18_{\mathrm{d}} \pm 0.005$ \\
Hydrolysate $(1 \%$ E/S ratio A. oryzae) & $3.44_{\mathrm{bc}} \pm 0.109$ \\
Hydrolysate $(6 \%$ E/S ratio A. oryzae) & $12.46_{\mathrm{a}} \pm 1.574$ \\
\hline in the same row, followed by different letters are significant differents $(\mathrm{P}<0.05)$.
\end{tabular}

A study conducted by Baehaki et al. (2015) found that fish protein hydrolysates derived from fish meat protein in which hydrolyzed using papain were producing four hydrolysates in MW range of 11.90-42.62 $\mathrm{kDa}$ [33]. While the protein content of fish gelatin and their hydrolysates were measured by using 96-well ELISA reader with bovine serum albumin (BSA) as standard in range $0-2 \mathrm{mg} / \mathrm{mL}$. The result has shown that the protein concentration of hydrolysates is increased gradually by increasing enzyme for hydrolysis (Table 2). Hydrolysate derived from flavourzyme hydrolysis has the highest protein content. 


\subsection{Free radical scavenging activity of gelatin hydrolysates.}

The bioactivities of fish gelatin hydrolysates as antioxidant measured by their capability to inhibit free radical 2,2-diphenyl-1-picrylhydrazyl (DPPH). This method is mention as a general method in order to determine the antioxidant capacity of bioactive compounds. The DPPH radical scavenging activity of an antioxidant is based on its ability to donate a hydrogen atom or an electron to stabilizing radicals, by converting it to the non-radical species [34]. In this work, the test was adopted from Clarke et al. (2013) in which the sample is mixed with DPPH solution, and 96\% ethanol was added, followed by incubation for 30 minutes [32]. Theoretically, the DPPH solution reacts with the bioactive compound to create the diphenylpycrylhydrazine. The absorbance of reaction then measured in wavelength of $540 \mathrm{~nm}$. The measurement was done using a 96-well microplate coupled with ELISA reader. The antioxidant activity determined by the ratio of sample absorbance with absorbance without bioactive compound then multiply $100 \%$.

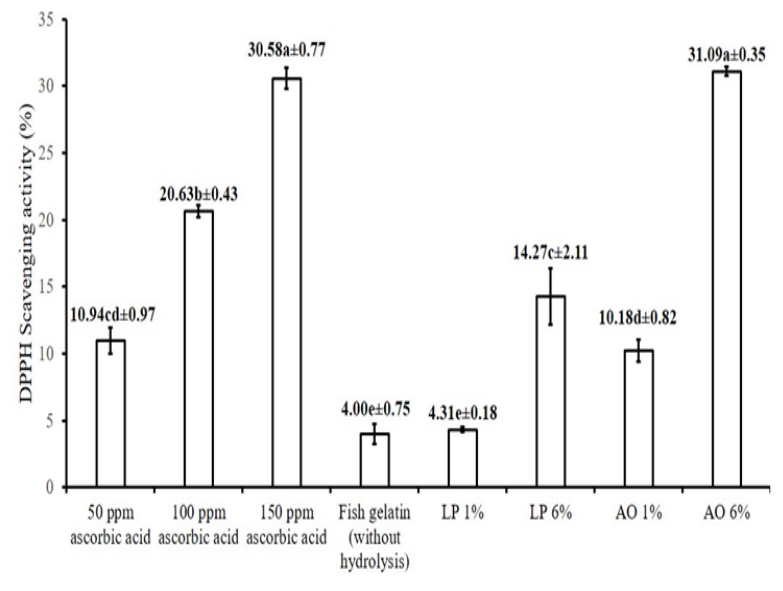

(a)

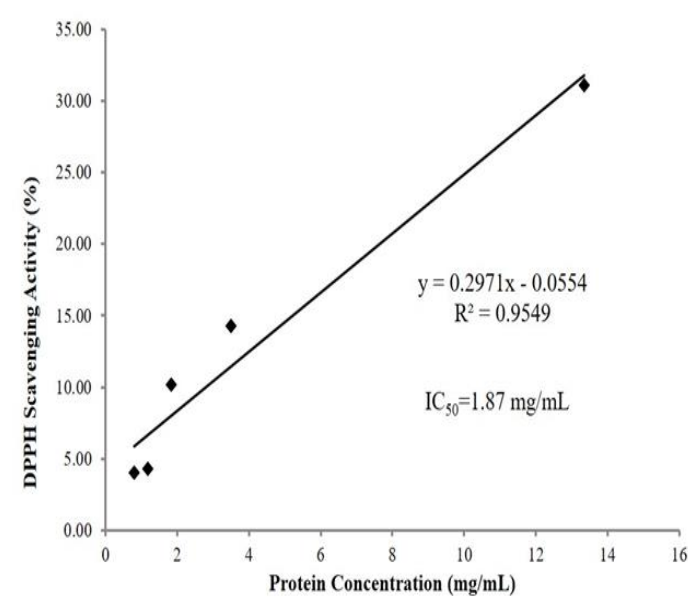

(b)

Figure 2. (a) Scavenging activity of fish gelatin and their hydrolysates compared to ascorbic acid. LP1\% means $1 \%[\mathrm{E} / \mathrm{S}]$ protease from $L$. plantarum $\mathrm{S} 31$ and $\mathrm{LP} 6 \%$ is $6 \%[\mathrm{E} / \mathrm{S}]$ protease from $L$. plantarum $\mathrm{S} 31$. AO $1 \%=1 \%$ $[\mathrm{E} / \mathrm{S}]$ ratio from protease of A. oryzae and AO $6 \%=6 \%[\mathrm{E} / \mathrm{S}]$ ratio from protease of $A$. oryzae. Values in each bar followed by different letters are significantly different $(\mathrm{P}<0.05)$; (b) Standard curve for IC50 value quantification of $\mathrm{DPPH} \bullet$-scavenging activity of fish gelatin hydrolysate from the bone of Pangasius catfish.

In this study, ascorbic acids (vitamin C) with concentration 50-150 ppm used as a positive control of scavenging activity. Figure $2 \mathrm{a}$ shows that radical scavenging of gelatin hydrolysates higher than gelatin before hydrolysis. Gelatin hydrolysate from a $6 \% \mathrm{E} / \mathrm{S}$ ratio of flavourzyme is higher than other hydrolysates. The highest one seems comparable to the free radical scavenging capacity of $150 \mathrm{ppm}$ ascorbic acid. Based on figure 2 also indicates that the inhibition of fish gelatin hydrolysates from $6 \% \mathrm{E} / \mathrm{S}$ ratios toward DPPH radical is outnumbered hydrolysates from $1 \% \mathrm{E} / \mathrm{S}$ ratios. A previous study has shown that gelatin hydrolysate from the skin of Amur sturgeon has antioxidant activity around 40\% [16] in which they are also using the ability of hydrolysate to neutralize the free radical of DPPH to measure the antioxidant activity, however, they use Alcalase for hydrolysis.

The $\mathrm{IC}_{50}$ value of gelatin hydrolysate from the bone of Indonesian Pangasius catfish also determined (figure $2 \mathrm{~b}$ ). It is because $\mathrm{IC}_{50}$ generally accepted as an indicator of the effectiveness of bioactive compounds wherein this term as an antioxidant through free radical DPPH inhibition. The $\mathrm{IC}_{50}$ fish gelatin hydrolysate from Indonesian Pangasius sutchi is 1.87 $\mathrm{mg} / \mathrm{mL}$. The IC50 value of Tilapia skin gelatin hydrolysate (TSGH) was $3.66 \mathrm{mg} / \mathrm{mL}$ [13]. You 
et al. (2010) reported the $\mathrm{IC}_{50}$ value of the DPPH--scavenging activity of Loach protein hydrolysate was $2.64 \mathrm{mg} / \mathrm{mL}$ [35].

The successful hydrolysis process was analyzed by sodium dodecyl sulfate polyacrilamide gel electrophoresis (SDS-PAGE). Figure 1 provides the electroforegram of fishbone gelatin and their hydrolysates. The figure shown that the fish gelatin before hydrolysis has thick band in higher MW, where the vague band depicted by the hydrolysates particularly at higher enzyme concentrations. Interestingly, the hydrolysates have a thicker band in lower MW that, in fact, the intact fish bone gelatin has too vague in that MW. It is indicated that the protease was hydrolyzed the gelatin. Accordingly, to support the result that not display of MW of hydrolysate derived from $1 \% \mathrm{E} / \mathrm{S}$ ratio of flavourzyme in electroforegram (for the reason of inappropriate SDS-PAGE picture), the quantification of MW through Rf values was done. Based on this quantification, the intact fish bone gelatin has MW $163 \mathrm{kDa}$, where their hydrolysates three-fold lower. Our previous work found that fishbone gelatin hydrolysates from similar species have MW $50 \mathrm{kDa}$ after hydrolyzed with flavourzyme [36]. Although the MW of the unhydrolyzed gelatin in this study slightly below our previous identification [31], the range is still in MW range of fish gelatin from the bone of Pangasius catfish. The intact gelatin from this species has MW of $\sim 100-116 \mathrm{kDa}, \sim 150-200 \mathrm{kDa}$, and $>225 \mathrm{kDa}$ [23]. In addition, the dominant factor that affects the MW of gelatin is protein hydrolysis during storage, concerning in this case, the gelatin was stored for few months before running to electrophoresis, while in our previous analysis, the gelatin had injected to a well of gel electrophoresis directly after extraction.

The protein content of fish gelatin hydrolysate derived from flavourzyme hydrolysis is larger than hydrolysates from protease L. plantarum S31 hydrolysis. The method for analyzing protein content in this research was by using bicinchoninic acid (BCA) assay kit. Besides affected by amino acid residues, the quantification of protein using BCA is also influenced by the peptide bonds or peptide backbones of protein [37], which means that more peptide bonds in protein solution imply to greater protein concentration. Hence, it is announced that the flavourzyme was actively hydrolyze the gelatin compared to protease L. plantarum S31, which also confirmed by their MW ranges. Flavourzyme is an endopeptidase and exopeptidase enzyme. They have wider and greater hydrolytic sites, thus their hydrolytic possibility also larger. Moreover, the purify of an enzyme in like manner contributes to their hydrolytic activity. The flavourzyme in this research was purified before commercialized, otherwise, the protease $L$. plantarum S31 was a crude extract even the specific activity $(2,000 \mathrm{U} / \mathrm{g})$ [26] over the flavourzyme $(500 \mathrm{U} / \mathrm{g})$.

The antioxidant activity through DPPH radical scavenging ability of fish gelatin increased subsequent hydrolysis. The radical scavenging activity of gelatin hydrolysate reach almost eight times higher than fish gelatin before hydrolysis. The activity of hydrolysates from flavourzyme hydrolysis is two-fold higher than hydrolysates from their counterpart even though their MW lower. These results contradict the Abuine et al. (2019) statement remarking that high molecular peptides have higher DPPH inhibition activity than low molecular peptides [10]. In fact, radical scavenging activity of hydrolysates depends on many factors, including peptide size, sequence, amino acid composition enzyme used, and degree of hydrolysis, among which amino acid composition and peptide sequence play a crucial role in determining the antioxidant power [15]. Lassoued et al. (2015) reporting that the presence of certain amino 
acids in the hydrolysate enhance scavenging activity of peptide, among of them like tryptophan, tyrosine, methionine, cysteine, histidine, and phenylalanine [18].

Some previous studies have observed the percentage of radical scavenging activity of fish gelatin and protein hydrolysates against DPPH in which using ascorbic acid as a positive control. As results, the DPPH scavenging activity of gelatin hydrolysates derived from skin gelatin of sole fish, thornback ray, black-barred halfbeak, and rainbow trout were $68 \%$ [15], $\sim 70 \%$ [18], 43.39\% [19] and $~ 40 \%$ [27] respectively. While radical scavenging activity of gelatin hydrolysates from bone of sole fish was $~ 62 \%$ [15]. Furthermore, protein hydrolysates from the skin of grass carp and collagen milkfish having DPPH scavenging activity as much as $40 \%$ [28] and 35\% [38], respectively. These data have shown us that gelatin hydrolysates from the bone of pangasius catfish have comparable DPPH scavenging activity than other hydrolysates. Indeed, the percent of inhibition toward DPPH still below, however comparing to the $\mathrm{IC}_{50}$ of other gelatin and protein hydrolysates, the gelatin from the bone of pangasius catfish, is still better. A study conducted by Chi et al. (2014) found that their hydrolysates derived from alcalase hydrolysis was lower than other enzymes hydrolysis [30]. They had found that the $\mathrm{IC}_{50}$ from that hydrolysate was $5.23 \mathrm{mg} / \mathrm{mL}$. Other researchers also mentioned the $\mathrm{IC}_{50}$ from their leading hydrolysates, surprisingly all of their hydrolysates have higher $\mathrm{IC}_{50}$ than our work. For example, the $\mathrm{IC}_{50}$ from skin gelatin hydrolysates of tilapia, amur sturgeon, and thornback ray was 3.66 [13], 5.38 [16], and $1.98 \mathrm{mg} / \mathrm{mL}$ [18] respectively. Although the $\mathrm{IC}_{50}$ antioxidant from protein hydrolysates is still higher than antioxidant compounds from a medical plant (such as IC $_{50}$ Veronica biloba fraction extracts which around $1.70 \pm 0.05 \mu \mathrm{g} / \mathrm{mL}$ ) [39], however, the protein has their own superiority regarding well-known as macronutrients so that generally safe and digestible. Thus, it is a signal that gelatin from the bone of pangasius catfish would be potential as a source of a bioactive peptide with antioxidant activity.

\section{Conclusions}

Fishbone gelatin hydrolysates from Pangasius catfish have a capacity as an antioxidant through inhibition free radical 2,2-diphenyl-1-picrylhydrazyl (DPPH). The activity of hydrolysate derived from enzymatic hydrolysis of $6 \%$ protease of $A$. oryzae was higher than gelatin before hydrolysis and other hydrolysates, even compared to $150 \mathrm{ppm}$ ascorbic acid. In terms of DPPH scavenging activity, the gelatin hydrolysate from the bone of Pangasius catfish has lower $\mathrm{IC}_{50}$ than previous fish-based hydrolysates.

\section{Funding}

This research received no external funding.

\section{Acknowledgments}

Thanks to Research Centre for Biotechnology, Indonesian Institute of Science for the protease from L. plantarum S31

\section{Conflicts of Interest}

The authors declare no conflict of interest. 


\section{References}

1. Sai-ut, S.; Benjakul, S.; Sumpavapol, P.; Kishimura, H. Antioxidant Activity of Gelatin Hydrolysate Produced from Fish Skin Gelatin using Extracellular Protease from Bacillus amyloliquefaciens H11. J Food Process Preserv 2014, 39, 394-403, https://doi.org/10.1111/jfpp.12244.

2. Mahmoodani, F.; Ghassem, M.; Babji, A.S.; Yusop, S.M.; Khosrokhavar, R. ACE Inhibitory Activity of Pangasius catfish (Pangasius sutchi) Skin and Bone Gelatin Hydrolysate. J Food Sci Technol 2014, 51, 18471856, https://doi.org/10.1007/s13197-012-0742-8.

3. Gómez-Guillén, M.; López-Caballero, M.; Aleman, A.; López de Lacey, A.; Giménez, B.; Montero, P. Antioxidant and Antimicrobial Peptide Fractions from Squid and Tuna Skin Gelatin. Le-Buhan E., Eds.; Transworld Research Network: Karela, India, Volume 661, 2010; pp. 89-115.

4. Wang, T.Y.; Hsieh, C.H.; Hung, C.C.; Jao, C.L.; Chen, M.C.; Hsu, K.C. Fish Skin Gelatin Hydrolysates as Dipeptidyl Peptidase IV Inhibitors and Glucagon-Like Peptide-1 Stimulators Improve Glycaemic Control in Diabetic Rats: A Comparison Between Warm- and Cold-water Fish. J Funct Foods 2015, 19, 330-340, https://doi.org/10.1016/j.jff.2015.09.037.

5. Fu, Y.; Zhao, X. In Vitro Responses of hFOB1.19 Cells Towards Chum Salmon ( Oncorhynchus keta) Skin Gelatin Hydrolysates in Cell Proliferation, Cycle Progression and Apoptosis. J Funct Foods 2013, 5, 1-10, https://doi.org/10.1016/j.jff.2012.10.017.

6. Amiza, M.A.; Wan Maizatul Shima, W.M.; Nor Hayati, I.; Nizaha Juhaida, M. Optimization of Gelatin Extraction Conditions from Cobia (Rachycentron canadum) Skin and Its Physicochemical Characteristics as Compared to Bovine Gelatin. Int Food Res J 2015, 22, 213-224.

7. Karim, A.A.; Bhat, R. Fish Gelatin: Properties, Challenges, and Prospects as An Alternative of Mammalian Gelatins. Food Hydrocoll 2009, 23, 563-576, https://doi.org/10.1016/j.foodhyd.2008.07.002.

8. Choonpicharn, S.; Jaturasitha, S.; Rakariyatham, N.; Suree, N.; Niamsup, H. Antioxidant and Antihypertensive Activity of Gelatin Hydrolysate from Nile Tilapia Skin. J Food Sci Technol 2015, 52, 3134-3139, https://doi.org/10.1007/s13197-014-1581-6.

9. Karayannakidis, P. D.; Zotos, A. Fish Processing By-Products as A Potential Source of Gelatin: A Review. J Aquat Food Prod Technol 2016, 25, 65-92, https://doi.org/10.1080/10498850.2013.827767.

10. Abuine, R.; Rathnayake, A. U.; Byun, H. Biological Activity of Peptides Purified from Fish Skin Hydrolysates. Fish Aquat Sci 2019, 22, 1-14, https://doi.org/10.1186/s41240-019-0125-4.

11. Zheng, L.; Yu, H.; Wei, H.; Xing, Q.; Zou, Y.; Zhou, Y.; Peng, J. Antioxidative Peptides of Hydrolysate Prepared from Fish Skin Gelatin using Ginger Protease Activate Antioxidant Response Element-Mediated Gene Transcription in IPEC-J2 Cells. J Funct Foods 2018, 51, 104-112, https://doi.org/10.1016/j.jff.2018.08.033.

12. Sun, L.; Zhang, Y.; Zhuang, Y. Antiphotoaging Effect and Purification of An Antioxidant Peptide from Tilapia (Oreochromis niloticus) Gelatin Peptides. J Funct Foods 2013, 5, 154-162, https://doi.org/10.1016/j.jff.2012.09.006.

13. Zhang, Y.; Duan, X.; Zhuang, Y. Purification and Characterization of Novel Antioxidant Peptides from Enzymatic Hydrolysates of Tilapia (Oreochromis niloticus) Skin Gelatin. Peptides 2012, 38, 13-21, https://doi.org/10.1016/j.peptides.2012.08.014.

14. Ngo, D.; Qian, Z.; Ryu, B.; Park, J. W.; Kim, S. In Vitro Antioxidant Activity of A Peptide Isolated from Nile Tilapia (Oreochromis niloticus) Scale Gelatin in Free Radical-Mediated Oxidative Systems. J Funct Foods 2010, 2, 107-117, https://doi.org/10.1016/j.jff.2010.02.001.

15. Viji, P.; Phannendra, T.S.; Jesmi, D.; Rao, B.M.; Das, P.H.D.; George, N. Functional and Antioxidant Properties of Gelatin Hydrolysates Prepared from Skin and Scale of Sole Fish. J Aquat Food Prod Technol 2019, 28, 976-986, https://doi.org/10.1080/10498850.2019.1672845.

16. Nikoo, M.; Benjakul S.; Ehsani, A.; Li, J.; Wu, F.; Yang, N.; Xu, B.; Jin, Z.; Xu, X. Antioxidant and Cryoprotective Effects of A Tetrapeptide Isolated from Amur Sturgeon Skin Gelatin. J Funct Foods 2014, 7, 609-620, https://doi.org/10.1016/j.jff.2013.12.024.

17. Razali, A.N.; Amin, A.M.; Sarbon, N.M. Antioxidant Activity and Functional Properties of Fractionated Cobia Skin Gelatin Hydrolysate at Different Molecular Weight. Int Food Res J 2015, 22, 651-660.

18. Lassoued, I.; Mora, L.; Nasri, R.; Jridi, M.; Toldra, F.; Aristoy, M.C.; Barkia, A.; Nasri, M. Characterization and Comparative Assessment of Antioxidant and ACE Inhibitory Activities of Thornback Ray Gelatin Hydrolysates. J Funct Foods 2015, 13, 225-238, https://doi.org/10.1016/j.jff.2014.12.042.

19. Abdelhedi, O.; Nasri, R.; Mora, L.; Toldrá, F.; Nasri, M.; Jridi, M. Collagenous Proteins from Black-Barred Halfbeak Skin as A Source of Gelatin and Bioactive Peptides. Food Hydrocoll 2017, 70, 123-133, https://doi.org/10.1016/j.foodhyd.2017.03.030.

20. Tkaczewska, J.; Bukowski, M.; Mak, P. Identification of Antioxidant Peptides In Enzymatic Hydrolysates of Carp (Cyprinus carpio) Skin Gelatin. Molecules 2018, 24, 1-15, https://doi.org/10.3390/molecules24010097.

21. Alemán, A.; Giménez, B.; Montero, P.; Gómez-Guillén, M. C. Antioxidant Activity of Several Marine Skin Gelatins. LWT - Food Sci Technol 2011, 44, 407-413, https://doi.org/10.1016/j.lwt.2010.09.003.

22. Qiu, Y.; Wang, Y.; Yang, X.; Zhao, Y.; Chi, C.; Wang, B. Gelatin and Antioxidant Peptides from Gelatin 
Hydrolysate of Skipjack Tuna (Katsuwonus pelamis) Scales: Preparation, Identification and Activity Evaluation. Mar Drugs 2019, 17, 1-17, https://doi.org/10.3390/md17100565.

23. Mahmoodani, F.; Ardekani, V.S.; See, S.F.; Yusop, S.M.; Babji, A.S. Optimization and Physical Properties of Gelatin Extracted from Pangasius Catfish (Pangasius sutchi) bone. J Food Sci Technol 2014, 51, 31043113, https://doi.org/10.1007/s13197-012-0816-7.

24. Budiarto, B.R.; Mustopa, A.Z.; Idarmawan, T. Characterization of Partially Extracellular Proteases from Bekasam-Isolated Lactobacillus plantarum S31 and Its Application to Hydrolyze Skimmed-Milk with Antibacterial Property. Int Food Res J 2016, 23, 340-349.

25. Cheng, L.; Mu, W.; Jiang, B. Thermostable L-Arabinose Isomerase from Bacillus stearothermophilus IAM 11001 for D-Tagatose Production: Gene Cloning, Purification and Characterisation. J Sci Food Agric 2010, 90, 1327-1333, https://doi.org/10.1002/jsfa.3938.

26. Herlina, N.; Mustopa, A.Z.; Surachma, R.S.; Triratna, L.; Kartina, G.; Alfisyahrin, W.N. Aktivitas Antibakteri dan Antioksidan Peptida Susu Kambing Hasil Hidrolisis dengan Protease Lactobacillus plantarum S31 (Antibacterial and Antioxidant Activity of Goat Milk Peptide Hydrolyzed with Protease of Lactobacillus plantarum S31). J Biol Indones 2019, 15, 23-31.

27. Ramezanzade, L.; Hosseini, S.F.; Nikkhah, M.; Arab-Tehrany, E. Recovery of Bioactive Peptide Fractions from Rainbow Trout (Oncorhynchus mykiss) Processing Waste Hydrolysate. Ecopersia 2018, 6, 31-40.

28. Cai, L.; Wu, X.; Zhang, Y.; Li, X.; Ma, S. Purification and Characterization of Three Antioxidant Peptides from Protein Hydrolysate of Grass Carp (Ctenopharyngodon idella) Skin. J Funct Foods 2015, 16, 234-242, https://doi.org/10.1016/j.jff.2015.04.042.

29. Yang, X.; Zhao, Y.; Qiu, Y.; Chi, C.; Wang, B. Preparation and Characterization of Gelatin and Antioxidant Peptides from Gelatin Hydrolysate of Skipjack Tuna ( Katsuwonus pelamis) Bone Stimulated by In Vitro Gastrointestinal Digestion. Mar Drugs 2019, 17, 1-18, https://doi.org/10.3390/md17020078.

30. Chi, C.; Wang, B.; Hu, F.; Wang, Y.; Zhang, B. Purification and Identification of Three Novel Antioxidant Peptides from Protein Hydrolysate of Bluefin Leatherjacket (Navodon septentrionalis) Skin. Food Res Int 2014, 73, 124-129, https://doi.org/10.1016/j.foodres.2014.08.038.

31. Atma, Y.; Lioe, H.N.; Prangdimurti, E.; Seftiono, H.; Taufik, M.; Fitriani, D.; Mustopa, A.Z. The ProportionRatio on Dipeptidyl Aminopeptidase-4 (DP-4) Inhibition by Gelatin Compared to Synthetic Sitagliptin. J Immunoass Immunochem 2019, 40, 386-395, https://doi.org/10.1080/15321819.2019.1613243.

32. Clarke, G.; Ting, K.N.; Wiart, C.; Fry, J. High Correlation of 2,2-Diphenyl-1-Picrylhydrazyl (DPPH) Radical Scavenging, Ferric Reducing Activity Potential and Total Phenolics Content Indicates Redundancy in Use of All Three Assays to Screen for Antioxidant Activity of Extracts of Plants from The Malaysian Rainforest. Antioxidants 2013, 2, 1-10, https://doi.org/10.3390/antiox2010001.

33. Baehaki, A.; Lestari, S.D.; Romadhoni, A.R. Hidrolisis Protein Ikan Patin Menggunakan Enzim Papain dan Aktivitas Antioksidan Hidrolisatnya. J Pengolah Has Pertan Indones 2015, 18, 230-239..

34. Chandrasekara, A.; Shahidi, F. Inhibitory Activities of Soluble and Bound Millet Seed Phenolics on Free Radicals and Reactive Oxygen Species. J Agric Food Chem 2011, 59, 428-436, https://doi.org/10.1021/jf103896z.

35. You, L.; Zhao, M.; Regenstein, J.M.; Ren, J. Purification and Identification of Antioxidative Peptides from Loach (Misgurnus anguillicaudatus) Protein Hydrolysate by Consecutive Chromatography and Electrospray Ionization-Mass Spectrometry. Food Res Int 2010, 43, 1167-1173, https://doi.org/10.1016/j.foodres.2010.02.009.

36. Atma, Y.; Lioe, H. N.; Prangdimurti, E.; Seftiono, H.; Taufik, M.; Mustopa, A. Z. Dipeptidyl Peptidase IV (DPP-IV) Inhibitory Activity of Ultrafiltration and Gel Filtration Fractions of Gelatin Hydrolysates Derived from Bone of Fish for Antidiabetes. Int J Adv Sci Eng Inf Technol 2019, 9, 2096-2103, https://doi.org/10.18517/ijaseit.9.6.10658.

37. He, F. BCA (Bicinchoninic Acid) Protein Assay Fanglian. Available online: https://bio-protocol.org/pdf/bioprotocol44.pdf (accessed on 18 Februari 2020)

38. Kusumaningtyas, E.; Nurilmala, M.; Sibarani, D. Antioxidant and Antifungal Activities of Collagen Hydrolysates from Skin of Milkfish (Chanos chanos) Hydrolyzed Using Various Bacillus Proteases. IOP Conf Ser Earth Environ Sci 2019, 278, 1-7, https://doi.org/10.1088/1755-1315/278/1/012040.

39. Hassan, A.; Ullah, H.; Israr M. The Antioxidant Activity and Phytochemical Analysis of Medicinal Plant Veronica biloba. Lett. Appl. NanoBioScience 2019, 8,732-738, 2019, doi: 10.33263/lianbs84.732738. 